\title{
Challenges to developing effective streptococcal vaccines to prevent rheumatic fever and rheumatic heart disease
}

This article was published in the following Dove Press journal:

Vaccine: Development and Therapy

2 May 2014

Number of times this article has been viewed

\author{
Abhinay Sharma \\ D Patric Nitsche-Schmitz \\ Department of Medical Microbiology, \\ Helmholtz Center for Infection \\ Research, Braunschweig, Germany
}

\begin{abstract}
Acute rheumatic fever is a sequela of Streptococcus pyogenes and potentially of Streptococcus dysgalactiae subsp. equisimilis infections. Acute rheumatic fever is caused by destructive autoimmunity and inflammation in the extracellular matrix and can lead to rheumatic heart disease, which is the most frequent cardiologic disease that is acquired in youth. Although effective treatments are available, acute rheumatic fever and rheumatic heart disease remain serious threats to human health, which affect millions and cause high economic losses. This has motivated the search for a vaccine that prevents the causative streptococcal infections. A variety of potential vaccine candidates have been identified and investigated in the past. Today, new approaches are applied to find alternative candidates. Nevertheless, several obstacles lie in the way of an approved $S$. pyogenes vaccine for use in humans. Herein, a subjective selection of promising vaccine candidates with respect to the prevention of acute rheumatic fever/rheumatic heart disease and safety regarding immunological side effects is discussed.
\end{abstract}

Keywords: autoimmune disease, side effects, M protein vaccine, molecular mimicry, coiledcoil, collagen binding, PARF

\section{Burden of streptococcal infections and sequelae}

Streptococcus pyogenes (group A Streptococcus) is a Gram-positive extracellular bacterial pathogen that causes a broad spectrum of diseases in humans. The spectrum of diseases ranges from rather uncomplicated pharyngitis and skin infections (impetigo, erysipelas) to scarlet fever and fatal invasive illnesses like necrotizing fasciitis and streptococcal toxic shock syndrome. Moreover, $S$. pyogenes causes the nonsuppurative immune sequelae acute rheumatic fever (ARF) and acute post-streptococcal glomerulonephritis. ${ }^{1}$

During the last decades, mortality rates due to $S$. pyogenes infections in the world's human population have decreased, particularly where socioeconomic conditions and access to medical care have improved. Still, despite the use of antibiotics, S. pyogenes remains a leading cause of high morbidity and mortality on a global scale. According to estimates of Carapetis et al, S. pyogenes is responsible for more than 700 million cases of purulent throat and skin infections, for 150,000 lethal invasive infections, and 1.8 million new cases of immune sequelae per year. ${ }^{2}$ The streptococcal immune sequelae alone claim another 350,000 human lives every year. ${ }^{2}$ About 18 million people are estimated to suffer from the consequences of $\mathrm{ARF}^{2}$

$\mathrm{ARF}$ is an autoimmune disease that presents in a variety of manifestations. The most feared consequence of ARF is rheumatic heart disease (RHD), which is the most frequent cardiovascular cause of death in school children and young adults in
Schmitz

Department of Medical Microbiology,

Helmholtz Center for Infection

Research, Inhoffenstrasse 7,

Braunschweig 38124, Germany

Tel +4953I 6I8I 4504

$\mathrm{Fax}+49531$ 6I8I 4499

Email patric.nitsche@helmholtz-hzi.de submit your manuscript | www.dovepress.com

Dovepress

http://dx.doi.org// 0.21 477/VDT.S45037
Vaccine: Development and Therapy 2014:4 39-54

(c) (i) (5) 2014 Sharma and Nitsche-Schmitz. This work is published by Dove Medical Press Limited, and licensed under Creative Commons Attribution - Non Commercial (unported, v3.0) License. The full terms of the License are available at http://creativecommons.org/licenses /by-nc/3.0/. Non-commercial uses of the work are permitted without any further

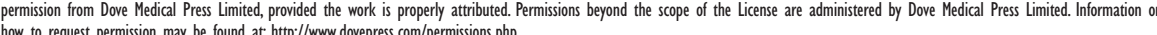
how to request permission may be found at: http://www.dovepress.com/permissions.php 
developing countries. ${ }^{2,3}$ In RHD, destructive autoimmune responses target the heart valve. ${ }^{4}$ The resulting damage leads to insufficient blood circulation, which severely affects the live quality and fitness of the patient. Very often, RHD progresses despite intensive anti-inflammatory and anti-congestive therapy. At later stages, valve replacement becomes the only viable therapeutic option. ${ }^{4}$

The highest prevalence of RHD in 5- to 14-year-old children is observed in developing and newly industrialized countries, amounting to 5.7 cases per 1,000 population in sub-Saharan Africa and 2.2 cases per 1,000 population in south-central Asia. ${ }^{2}$ Even in industrialized countries, the prevalence is as high as 0.3 cases per 1,000 population. ${ }^{2}$ The substantial impact of $S$. pyogenes on human health and the associated high economic losses have motivated a long, extensive, and continuous search for a vaccine; a search that, after more than half a century, has not yet led to a licensed product on the market that prevents $S$. pyogenes infections or their sequelae in humans.

\section{ARF and RHD}

\section{Pathology of ARF and RHD}

$\mathrm{ARF}$ is caused by autoimmune responses that rise during untreated or inadequately treated infection by $S$. pyogenes and, potentially, by Streptococcus dysgalactiae subsp. equisimilis (SDSE). ${ }^{5-7}$ Associations with genetic markers such as major histocompatibility complex antigen phenotypes suggest a genetic predisposition for ARF in some individuals. ${ }^{8-18}$ Manifestations of ARF comprise arthritis, erythema, carditis, and neurological dysfunctions (Sydenham chorea). ${ }^{19,20}$ Neurological manifestation may cause or exacerbate pediatric autoimmune neuropsychiatric disorders associated with streptococcal infection (PANDAS), a disorder that is not yet established as a unique clinical entity (Figure 1). ${ }^{21-23}$ As recently summarized by Tandon et al, the histopathology of ARF indicates that extracellular matrix (ECM) components are the common target of autoimmune responses in the various manifestations of ARF. Most of the affected tissues heal completely after the acute episode of ARF and no visible damage remains. However, about one out of three ARF patients develops RHD, in which the autoimmune responses damage the heart valves irreversibly. Most often the mitral valve, less often the aortic valve, and rarely the pulmonary or tricuspid valve is affected by RHD and the valvular degenerations are characterized by scarring and neovascularization. ${ }^{4}$

ARF often manifests itself in rheumatic carditis. Rheumatic carditis often presents as a pancarditis that affects all three layers of the heart wall: endocardium, myocardium,

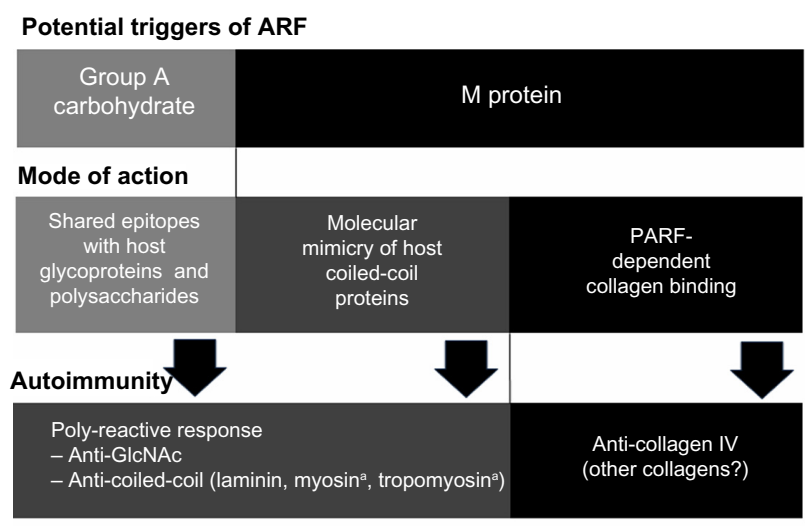

Target

Extracellular matrix, basement membrane and cell surface receptors
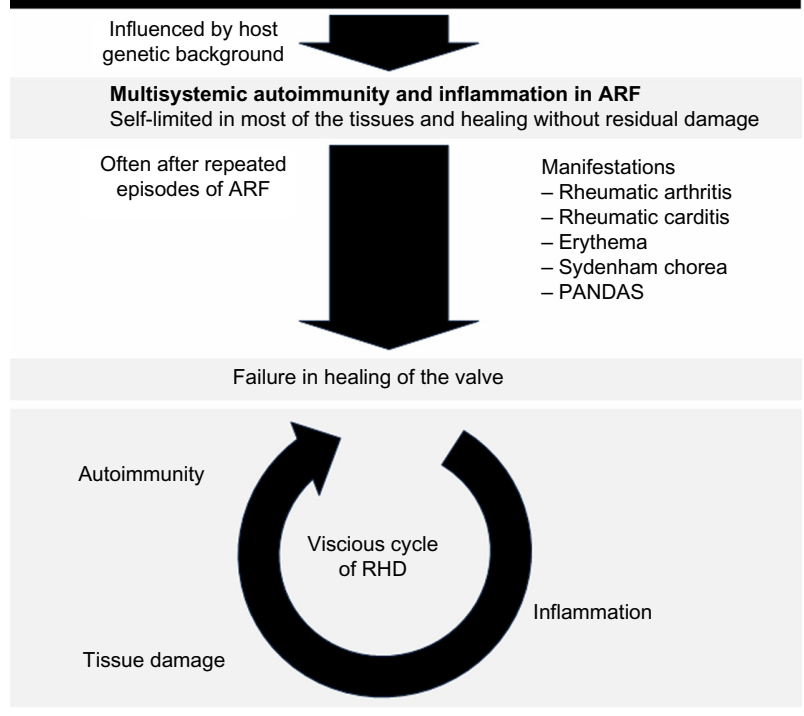

Figure I Triggers and pathogenesis of ARF and RHD.

Note: aProbably not a primary target in ARF pathogenesis as it is an intracellular protein.

Abbreviations: ARF, acute rheumatic fever; GlcNAc, N-acetylglucosamine; PANDAS, pediatric autoimmune neuropsychiatric disorders associated with streptococcal infection; PARF, peptide associated with rheumatic fever; RHD, rheumatic heart disease.

and pericardium. Pathohistologically, rheumatic carditis is characterized by interstitial deposition of immunoglobulins and complement factors and by cellular infiltrates in the cardiac tissue. ${ }^{4,24}$ The cellular infiltrates contain macrophages and T-lymphocytes, particularly increased numbers of mature circulating T-helper cells (cluster of differentiation $4^{+}$T-cells). ${ }^{25-27}$ Ongoing inflammation in the affected heart is indicated by elevated levels of cytokines such as interleukin-1 and interleukin-2, interferon- $\gamma$, tumor necrosis factor- $\alpha$, and by higher amounts of the corresponding cytokine receptors. ${ }^{25}$ T-cell autoimmunity starts with reactivity against dominant T-cell epitopes of autoantigens. Subsequently, degeneracy of antigen presentation by major histocompatibility complex molecules and degenerate recognition by the T-cell receptor 
lead to reactivity against a growing number of other autoepitopes, an effect that is known as epitope spreading and causes diversification of the autoimmune response..$^{28-31}$

As in other manifestations of ARF, the histopathology of rheumatic carditis indicates that the ECM is the target of the causative autoimmune responses. In contrast to rheumatic carditis, the myocardium is spared in subsequent RHD and the degenerative processes are limited to the heart valves. While most of the other affected tissues heal completely after the acute episode of rheumatic fever, the ability of the heart valves to resolve the destructive processes of ARF appears to be limited. This could be the cause of RHD and its heart valve specificity (Figure 1). ${ }^{4}$

\section{Streptococcal factors involved in ARF/RHD pathogenesis}

A variety of streptococcal factors have been implicated in the molecular pathogenesis of ARF. This variety includes superantigens, the group A carbohydrate, the hyaluronic acid capsule, and the $M$ protein. ${ }^{7}$ Superantigens trigger the exaggerated inflammation in acute invasive infections that contributes to streptococcal toxic shock syndrome. ${ }^{32-36}$
Their mitogenic activity on T-lymphocytes may generate or shape the autoimmunity in ARF by expanding certain polyclonal populations of lymphocytes, if accompanied by a break of immune tolerance to autoantigens. ${ }^{32,37}$ However, since experimental evidence is missing, it remains speculative whether superantigens are a specific cause of the autoimmunity that is observed in the ECM of ARF/RHD patients. Investigations on experimental encephalomyelitis and collagen-induced arthritis indicate that superantigens may exacerbate or reactivate autoimmune reactions, but there are no indications that they trigger autoimmunity. ${ }^{38,39}$ Deposition of immunoglobulin and complement factors in the diseased heart indicates participation of humoral immune responses in ARF pathogenesis. ${ }^{24}$ Autoantibodies against collagen, cardiac myosin, heart valve glycoproteins, and antigens of the sarcolemma membrane circulate in ARF or RHD patients. ${ }^{5,25,40-44}$ Some of these autoantibodies cross-react with streptococcal products such as the group A carbohydrate, components of the bacterial cell membrane, or the surfacelocated M protein. ${ }^{45,46}$ Antibodies against group A carbohydrate circulate in patients with rheumatic valvular disease. ${ }^{47}$ These antibodies may contribute to autoimmunity and cardiac

Table I Acute rheumatic fever vaccine candidates discussed in this review

\begin{tabular}{|c|c|c|c|}
\hline Antigen & Advantages & Disadvantages & Stage \\
\hline \multicolumn{4}{|l|}{ Non-M protein vaccine } \\
\hline Group A carbohydrate ${ }^{64}$ & $\begin{array}{l}\text { Conserved in all Streptococcus pyogenes } \\
\text { Prevents colonization in humans }\end{array}$ & $\begin{array}{l}\text { Potential trigger of autoimmunity } \\
\text { in humans }{ }^{42,47,48}\end{array}$ & Preclinical \\
\hline C5a peptidase ${ }^{117-120}$ & $\begin{array}{l}\text { Potentially, high emm type coverage and cross- } \\
\text { protection against other streptococcal pathogens } \\
\text { Not implicated in autoimmune side effects } \\
\text { Induced IgA response in saliva in mice }\end{array}$ & None reported & Preclinical \\
\hline \multicolumn{4}{|c|}{ Type-specific $\mathbf{M}$ protein vaccines - $\mathbf{N}$-terminus based } \\
\hline $\begin{array}{l}\text { Hexavalent tandem } \\
\text { antigen } 108,156,157\end{array}$ & $\begin{array}{l}\text { Protective in humans } \\
\text { No autoimmunity observed }\end{array}$ & Low emm type coverage & $\begin{array}{l}\text { Successful in Phase I } \\
\text { Clinical trial Phase II } \\
\text { Clinical trial completed }\end{array}$ \\
\hline $\begin{array}{l}\text { 26-valent combination } \\
\text { of tandem antigens } \\
\left(\text { StreptAvax }{ }^{T M}\right)^{108,123,158}\end{array}$ & $\begin{array}{l}\text { Protective in humans } \\
\text { No autoimmunity observed }\end{array}$ & Limited emm type coverage & $\begin{array}{l}\text { Successful in Phase I } \\
\text { Clinical trial Phase II } \\
\text { Clinical trial completed }\end{array}$ \\
\hline $\begin{array}{l}\text { 30-valent combination } \\
\text { of tandem antigens }^{104,108,159}\end{array}$ & Increased emm type coverage & $\begin{array}{l}\text { Limited emm type coverage } \\
\text { despite bactericidal cross-reactivity } \\
\text { against non-vaccine emm types }\end{array}$ & Preclinical \\
\hline \multicolumn{4}{|c|}{ M protein vaccines - conserved C-repeat based } \\
\hline StreptlnCor ${ }^{137-140}$ & $\begin{array}{l}\text { Induced cellular and humoral responses, mucosal } \\
\lg \mathrm{A} \text { and systemic } \lg \mathrm{G} \text { production in mice } \\
\text { Cross-reaction against four non-vaccine } \\
\text { M types shown } \\
\text { No autoimmunity observed }\end{array}$ & $\begin{array}{l}\text { Limits of emm type coverage not } \\
\text { known }\end{array}$ & Preclinical \\
\hline $\begin{array}{l}\text { PI45 and derivatives } \mathrm{J} 8 \\
\text { and } \mathrm{J} / 4^{143,160}\end{array}$ & $\begin{array}{l}\text { Human antibodies against PI } 45 \text { cross-react with } \\
\text { different emm types }\end{array}$ & $\begin{array}{l}\text { Limited emm type coverage } \\
\text { despite cross-reactivity }\end{array}$ & Preclinical \\
\hline Multivalent $\mathrm{JI} 4_{\mathrm{i}}{ }^{106}$ & $\begin{array}{l}\text { Broader emm type coverage than monovalent } \\
\text { C-repeat region vaccine }\end{array}$ & $\begin{array}{l}\text { Limits of emm type coverage not } \\
\text { known }\end{array}$ & Preclinical \\
\hline
\end{tabular}

Note: Preclinical refers to animal and/or natural human infection studies. Abbreviation: Ig, immunoglobulin. 
involvement as both group A carbohydrate and heart valve glycoproteins contain N-acetylglucosamine (GlcNAc), and thus share similar or identical epitopes. ${ }^{42}$ The GlcNAc monosaccharide subunit is a component of many N-glycosylated proteins and glycosaminoglycans, such as hyaluronic acid. As such, GlcNAc is ubiquitous in the host's ECM, in the cell calyx, and on the cell surface. Thus, autoimmune responses against GlcNAc may contribute to the different manifestations of ARF in a variety of host tissues.

Notably, monoclonal anti-GlcNAc antibodies derived from ARF patients cross-reacted with M protein type 5 (M5) and M6. ${ }^{48}$ The M protein (Figure 2) is a cell-surface protein, major virulence factor, and immunological determinant of S. pyogenes and SDSE. ${ }^{49-51}$ Hypervariability in the N-terminal sequence of $\mathrm{M}$ protein is the basis for the Lancefield serological division of $S$. pyogenes in M types. Nucleotide sequencing of the hypervariable portion of the emm gene, which encodes the $M$ protein, has replaced serological $M$ typing and is nowadays exploited for identification of different serotypes of $S$. pyogenes or SDSE and their division in emm types. ${ }^{52,53}$

$\mathrm{M}$ proteins dimerize to form thread-like molecules with extended $\alpha$-helical coiled-coil regions. ${ }^{54,55}$ They share this

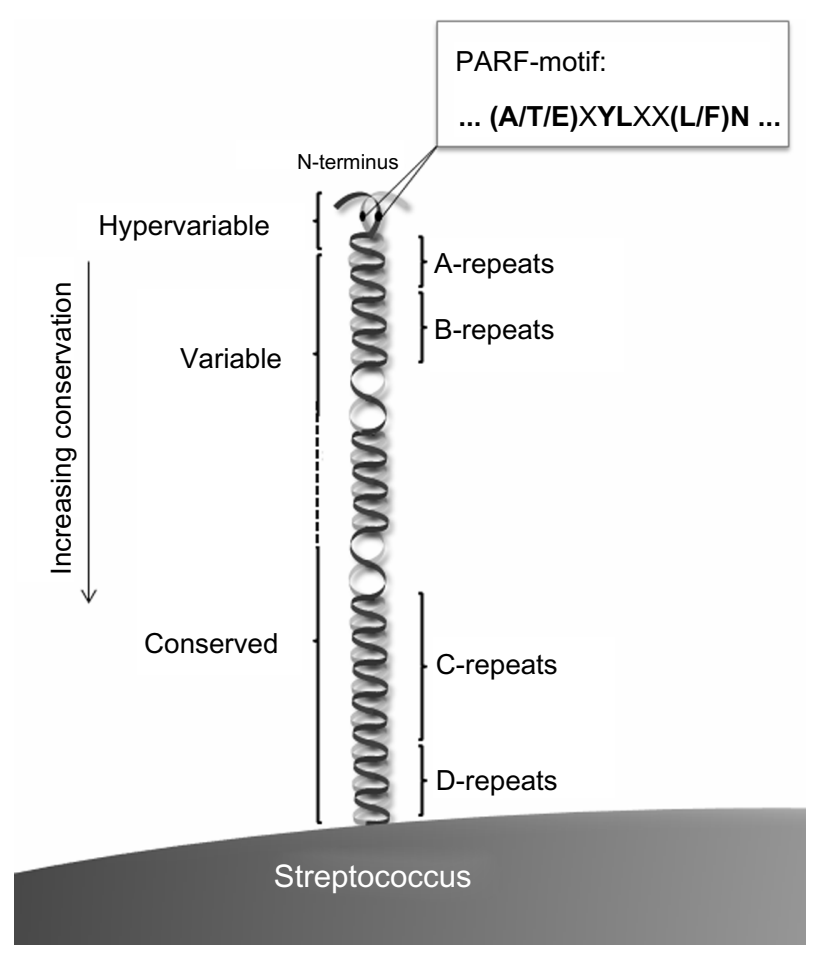

Figure 2 Schematic representation of the dimeric coiled-coil M protein on the streptococcal surface. $\mathrm{N}$-terminal localization of the PARF motif and its consensus sequence are indicated. Sequence conservation between different $M$ types increases in $\mathrm{C}$-terminal direction. A hypervariable, variable, and conserved region can be distinguished and the $M$ proteins comprise an A-, B-, C-, and D-repeat region as indicated.

Abbreviation: PARF, peptide associated with rheumatic fever. structural feature with several host proteins such as $\alpha$-keratin, human heart myosin, tropomyosin, and laminin. Such structural similarities are the basis for immunological crossreactivity with epitopes in streptococcal and host molecules which, known as a cause for autoimmunity, is referred to as molecular mimicry. ${ }^{56,57}$ This mimicry is considered as a triggering step in ARF pathogenesis, ${ }^{58,59}$ which is supported by the finding that higher concentrations of cross-reactive antibodies circulate in the blood of ARF/RHD patients as compared to healthy individuals. ${ }^{60}$ Anti-coiled-coil autoantibodies from ARF patients differ in reactivity from anti-cardiac antibodies in post-cardiotomy or heart failure patients. This supports the notion that coiled-coil autoimmune responses are triggered by molecular mimicry and are a cause of carditis rather than being merely a consequence of the cardiac damage itself. ${ }^{20,61}$ Monoclonal antibodies derived from ARF/RHD patients were polyreactive and bound to $\mathrm{M}$ protein, aforementioned human coiled-coil proteins, as well as GlcNAc. ${ }^{20,48}$ Antibodies with a similar reactivity could also be raised in mice by injection of $S$. pyogenes. ${ }^{62,63}$ Such polyreactive antibodies could play a crucial role in rheumatic carditis, as suggested by their cytotoxicity and tissue localization. ${ }^{20}$ Both group A carbohydrate and $\mathrm{M}$ protein are potential triggers of the polyreactive immune response. However, rabbits immunized with group A carbohydrate conjugated to tetanus toxoid have failed to mount such responses. ${ }^{64}$ While contribution of group A carbohydrate cannot be excluded, there is evidence for the induction of polyreactive responses by $\mathrm{M}$ protein.

Myosin cross-reactive antibodies recognize epitopes in M5, M6, and M19, which is indicative of molecular mimicry. ${ }^{65-69}$ The molecular mimicry hypothesis was further supported by isolation of cross-reactive T-cell clones from myocardial and valvular lesions of RHD patients ${ }^{70}$ that reacted with both M5 and cardiac myosin. However, the histopathological observations in rheumatic carditis do not support that cardiac myosin is a primary target for the autoimmune responses in ARF/RHD. ${ }^{4}$ Myosin and tropomyosin are coiled-coil proteins of the muscle and therefore are shielded by the sarcolemma of the myocyte. Thus, they are not accessible to the extracellular immune system as long as the muscle cell is intact. This notion is in accordance with the fact that rheumatic carditis in ARF presents as an interstitial carditis with cellular infiltrates and fibrinoid degeneration. ${ }^{4}$

Histological signs of myocarditis are rarely observed and markers for myocardial damage, such as troponins and creatine kinase, are not significantly elevated in ARF patients. $^{4,71,72}$ Therefore, instead of myosin, GlcNAccontaining macromolecules and coiled-coil proteins in the 
ECM, basement membranes, or on the cell surface may be the primary targets of the polyreactive autoimmune responses in ARF. One prominent example is laminin that forms a triple-helical coiled-coil and is recognized by monoclonal antibodies from patients with rheumatic carditis. ${ }^{73}$ Taken together, there is both evidence for a limitation of autoimmunity to extracellular structures in ARF and $\mathrm{RHD}^{4}$ and conclusive indications for molecular mimicry and resulting polyreactive immunity as one of the possible causes of the destructive autoimmunity (Figure 1). ${ }^{58,59}$

\section{Role of collagen binding and the peptide associated with rheumatic fever (PARF) in ARF and RHD}

So far, molecular mimicry is shown only for a limited number of M protein types including M5, M6, and M19. ${ }^{65-69}$ S. pyogenes isolates of M18 have, however, caused two significant peaks of ARF incidence in Utah, USA. ${ }^{74,75}$ These isolates produced and were thickly encapsulated by hyaluronic acid. Hyaluronic acid is not only produced by streptococci, this polysaccharide is also produced by mammalian cells and an abundant component of the human ECM. Because of this duality, it is tempting to speculate about a role of the hyaluronic acid capsule of $S$. pyogenes in the induction of autoimmunity. As a polysaccharide with repetitive epitopes, hyaluronic acid may crosslink B-cell receptors. This may activate specific B-cells as shown for other polysaccharides. ${ }^{76}$ In connection with a break in immune tolerance, the clonal expansion and maturation of specific B-lymphocytes may lead to autoimmunity of hyaluronic acid and disease. However, autoimmune responses specific for hyaluronic acid have not been demonstrated in patients with either ARF or RHD. In an alternative concept, the hyaluronic acid capsule is thought to bind and aggregate collagen on the streptococcal surface, evoking the production of collagen autoantibodies. ${ }^{44}$ Hyaluronic acid is also produced in high quantities by Streptococcus equi subsp. zooepidemicus, ${ }^{77,78}$ which lacks rheumatogenic potential but causes acute post-streptococcal glomerulonephritis. ${ }^{79,80}$ Isolated from animal tissues or from $S$. equi subsp. zooepidemicus culture, hyaluronic acid is widely used as a cosmetic filler without immune complications. Thus, hyaluronic acid alone would seemingly not be sufficient to trigger an autoimmune disease. If capable of triggering autoimmunity, hyaluronic acid would apparently require a hitherto unknown cofactor.

Some M proteins trigger autoimmunity against collagen IV by binding to this ECM protein. ${ }^{43,44,81}$ Collagens of types I-IV are bound by different types of $\mathrm{M}$ proteins including S. pyogenes
M3 and M31 and M proteins of SDSE. These interactions depend on an $(\mathrm{A} / \mathrm{T} / \mathrm{E}) \mathrm{XYLXX}(\mathrm{L} / \mathrm{F}) \mathrm{N}$ octapeptide motif that, if present, is located in the N-terminal type-specific part of the $\mathrm{M}$ protein (Figure 2) ) $^{4,81,82}$ and facilitates streptococcal colonization of the ECM. ${ }^{44,83} \mathrm{M} 3$ and other collagen-binding M proteins that carry the $(\mathrm{A} / \mathrm{T} / \mathrm{E}) \mathrm{XYLXX}(\mathrm{L} / \mathrm{F}) \mathrm{N}$ motif trigger production of anti-collagen IV antibodies when injected into mice. ${ }^{43,44,81}$ Collagen IV is an important constituent of basement membranes that lie beneath and support the endothelia. This includes the endothelia that line the heart valves. Therefore, collagen IV is considered as a potential target of the autoimmune responses that lead to or aggravate valvular damage in RHD. ${ }^{4,43,44,81}$ Elevated titers of anti-collagen IV autoantibodies were found in ARF and RHD patients as compared to healthy individuals, ${ }^{43,44}$ implicating anti-collagen responses in ARF/ RHD pathogenesis. Therefore, the collagen-binding octapeptide motif was named PARF.4 ${ }^{43}$ Examination of human sera indicates that collagen autoimmunity is already induced after pharyngitis, before the onset of ARF. This suggests that the collagen autoimmune response is causative for the immune disease rather than a consequence of the tissue damage in $\mathrm{ARF}$ and RHD. ${ }^{7,44}$

Collagen autoantibodies that are produced by mice in response to injection of PARF-positive collagen-binding $\mathrm{M}$ proteins do not cross-react with the $\mathrm{M}$ protein. This indicates that the autoimmune reactions against collagen, other than autoimmunity against coiled-coil proteins, are not caused by molecular mimicry. Instead, collagen-binding $\mathrm{M}$ proteins appear to alter the presentation of collagen as an auto-antigen in a hitherto unknown way, leading to a break in immune tolerance. ${ }^{43,44}$ The precise molecular mechanism by which PARF induces anti-collagen responses is not yet elucidated but may be based on conformational changes in the collagen molecule upon M protein binding. Goodpasture syndrome, a collagen IV autoimmune disease that affects the lungs and kidneys, is a proven example of a "conformeropathy", ${ }^{84}$ and similar effects may play a role in ARF.

$M$ proteins require PARF to endow streptococci with a high binding capacity for a variety of collagens, including collagen IV. ${ }^{82}$ Retrospectively, streptococcal emm types that bear collagen-binding $M$ proteins with a PARF motif had a high epidemiological relevance. Based on a worldspanning meta-analysis, ${ }^{85}$ type 3 was the most prevalent emm type (M3) that binds collagen via PARF, amounting to $7 \%$ of the $S$. pyogenes isolates. ${ }^{82}$ Despite lacking a PARF motif, M1 binds collagens I and VI with high affinity and collagen IV with low affinity. ${ }^{86}$ The whole bacterial cells, however, have a low binding capacity 
for collagens I and IV as compared to PARF-positive streptococci (Nitsche-Schmitz, unpublished data, 2013). M1 binds collagen VI in a non-collagenous region, which suggests principal mechanistic differences as compared to the interaction between collagen and PARF. Until now it has not been studied whether M1 and other PARF-negative collagen-binding $\mathrm{M}$ proteins are able to trigger a collagen autoimmune response and, if so, whether these immune responses are associated with ARF/RHD (Figure 1). Hence, the epidemiological relevance of collagen-binding $\mathrm{M}$ proteins and collagen autoimmunity in the pathogenesis of ARF and RHD is not yet fully fathomed and may be even higher than currently estimated. ${ }^{82}$

Despite an increasing understanding of ARF pathogenesis (Figure 1), further research is needed to gain precise and comprehensive knowledge about the triggering factors of the disease, as this may pave the way to safe vaccines.

\section{Role of SDSE in ARF}

As in many other regions of the world, S. pyogenes is the predominant streptococcus isolated from pharyngitis - including tonsillitis - in the USA. This may be the reason why early epidemiological studies from the USA linked ARF to throat infections caused by $S$. pyogenes only. ${ }^{5,87}$ Notably, in certain high prevalence regions of ARF and RHD, throat infections with $\beta$-hemolytic streptococci have a different epidemiology from many other parts of the world. For instance, more than $60 \%$ of the throat isolates that were taken from a population of indigenous Australians in the Northern Territory of Australia belonged to the subspecies SDSE, exceeding the isolation rate of $S$. pyogenes. ${ }^{88}$

SDSE is the most frequent cause for group $\mathrm{C}$ and $\mathrm{G}$ streptococcal infections in humans. ${ }^{52,89}$ The spectrum of SDSE infections includes pharyngitis and skin infections and there are conceivable indications that infection with SDSE can also cause ARF. ${ }^{6,7}$ This subspecies caused $75 \%$ of the streptococcal pharyngitis cases that occurred in 1978 in Lagos, Nigeria, which is another high prevalence region for ARF/RHD. ${ }^{90}$ Both in Lagos and in the Northern Territory, $S$. pyogenes was the predominant species in skin infections. Such epidemiological observations from high prevalence regions are challenging the previous picture of ARF etiology that was limited to $S$. pyogenes pharyngitis. They suggest that either $S$. pyogenes skin infections, throat infections with SDSE, or both are also causative for ARF., ${ }^{6,43,91}$ Other than for throat infections, ${ }^{5,44}$ experimental or epidemiological evidence that streptococcal skin infections cause autoimmunity or ARF is missing.
SDSE seems to bear an underestimated rheumatogenic potential. The vast majority of SDSE strains that colonize or infect humans carry M proteins like S. pyogenes. ${ }^{52,92}$ Mice mounted anti-myosin titers in response to injection of SDSE isolates from the human throat, most likely due to molecular mimicry of the M protein. This may be one reason for the high prevalence of ARF in the community of indigenous Australians in which these isolates prevailed. ${ }^{6}$ Meta-analysis of emm typing data from three communities of indigenous Australians revealed an overall rate of $5.9 \%$ SDSE isolates with a collagenbinding PARF motif, which may be another cause for the high prevalence of ARF in these people. ${ }^{82,93}$ Rates of SDSE or $S$. pyogenes isolates with PARF-positive collagen-binding M proteins exceeded $10 \%$ in different geographic regions and in different periods of time. ${ }^{82}$

Despite the experimental evidence for triggers of ARFassociated autoimmunity in SDSE and indications for the high epidemiological relevance of SDSE throat infections in high incidence regions, the role of this streptococcal subspecies in ARF requires further examination. In the meantime, SDSE should not be neglected as a potential cause for an autoimmune disorder that can cause severe cardiac complications.

\section{The plethora of S. pyogenes emm types, their geographic distribution, and consequences for vaccine development}

Due to hypervariability, the $5^{\prime}$-sequence of the emm gene is a valuable genotype marker for $S$. pyogenes. More than 200 distinct emm types are known and recorded in the database of the Centers for Disease Control and Prevention (Atlanta, GA, USA; ftp://ftp.cdc.gov/pub/infectious diseases/biotech/ tsemm/). Emm typing studies from all over the world describe the plethora of genetically diverse $S$. pyogenes bacteria and their geographic distribution. ${ }^{85}$ In addition, whole genome sequencing has shed light on marked genetic differences that occur even between $S$. pyogenes bacteria of the same emm type. ${ }^{94-96}$ Pathogenomics of $S$. pyogenes suggests associations between genotypes or clones and the clinical manifestations of the infections. ${ }^{94,95,97,98}$ However, many of the reported correlations between genetic markers and the clinical picture remain ambiguous, ${ }^{99}$ such as the concept of rheumatogenic M types. Based on the prevalence of M1, M3, M5, M6, M18, M19, and M24 in endemic outbreaks of ARF in the USA, it was suggested that the rheumatogenic potential of $S$. pyogenes is limited to these and a few other M types. ${ }^{100}$ Worldwide emm 
typing data do not support this concept, as the previously identified rheumatogenic $\mathrm{M}$ or corresponding emm types are rare in some of today's high prevalence regions for ARF/RHD, where the emm type distribution is more diverse and not clearly dominated by certain emm types. ${ }^{99,101}$ Consequently, there is no general epidemiological basis upon which rheumatogenic emm types can be selected as targets for a potential ARF-specific vaccine. Still, the presence of rheumatogenic factors may be limited to certain streptococcal strains and development of a specific vaccine against the rheumatogenic infections may become feasible with a comprehensive knowledge of these factors and their distribution in streptococci.

A more attractive alternative lies in the development of general vaccines that cover all S. pyogenes bacteria and reduce both the burden of streptococcal sequelae and incidence of acute severe infections. A meta-study on worldspanning emm typing data of $S$. pyogenes, which comprised 102 datasets about 38,081 isolates, identified emml (18.3\%) as the most common emm type worldwide followed by emm12 (11.1\%), emm28 (8.5\%), emm3 (6.9\%), and emm 4 (6.9\%). However, emm type distribution differed considerably by region and by infection manifestation..$^{85}$ Analysis of emm typing data from 16 countries revealed a bimodal distribution of Simpson's reciprocal index (SRI), which is a measure for the genotypic diversity and evenness of the genotype distribution. ${ }^{99}$ According to Smeesters et al, the countries could be divided into three groups based on emm type diversity and shared emm types. The first group comprised Japan, Korea, Mexico, and countries of North America and Western Europe, where emm type diversity was low (SRI 8-13) and the spectrum of emm types similar, with only a few predominating types. China and countries from Eastern Europe formed a second group of countries with low emm type diversity (SRI 10-12) and differing from the first group in the predominant emm types. The third group consisted of Brazil, Ethiopia, Israel, India, Nepal, Australia, and Fiji, thus comprising current high prevalence regions of ARF/RHD. Emm type diversity was high (SRI 27-50) and no predominant emm types were observed in countries of this group. Moreover, circulating emm types differed between the countries of the third group and from the emm types found in the first two groups. Taken together, emm typing suggests that an effective $S$. pyogenes vaccine would have to protect against a vast and region-specific variety of genotypes. Development of such a vaccine may be particularly difficult in countries of Smeesters et al's third group that comprises high prevalence regions for $\mathrm{ARF} / \mathrm{RHD}$ and shows the highest genotypic variety of the targeted pathogen. ${ }^{99}$
Probably driven by natural immunity to reinfection with $S$. pyogenes of the same emm type and by emergence of clones with increased fitness, the regional distribution of emm types is highly dynamic. ${ }^{102,103}$ This is another issue that has to be considered in vaccine development. Replacement of type emm 1 by emm 6 was observed within a short period of time in a semi-closed community in the USA. On the one hand, this observation highlights the type specificity of protective responses to natural infection, indicating that reactivity against conserved antigens of the streptococcal surface plays a minor role in natural immunity against $S$. pyogenes. On the other hand, replacement of vaccine emm types by other newly developing emm types or by expanding clones of non-vaccine emm types that are already present in the geographic region or introduced by traveling humans, could lead to a short-lived protection by type-specific vaccines. ${ }^{99,103}$

Emm typing has delivered and continues to deliver valuable information for vaccine development.

\section{Demands and obstacles in the development of a vaccine against ARF}

The obstacles in the development of $S$. pyogenes vaccines in general comprise the enormous antigenic variation in S. pyogenes. This variation limits the number of conserved protective antigens. Consequently, it is difficult to cover the whole variety of circulating $S$. pyogenes with a vaccine. However, two approaches may help overcome this problem. One is the combination of different antigens in a vaccine formulation, a multivalent vaccine. Another approach is the design of a region-specific vaccine that is tailored to target the circulating S. pyogenes serotypes in a defined geographic region. However, due to the spatiotemporal dynamics of streptococcal populations, the protective effect of region specific vaccines would only be predicted to be short-lived (see The plethora of S. pyogenes emm types, their geographic distribution, and consequences for vaccine development). This would create a need for regular surveillance and frequent redevelopment of the vaccines, which may be difficult to support financially.

A vaccine that prevents ARF would have to induce bactericidal immune responses that eradicate the streptococcus early during infection or colonization, ie, by induction of mucosal immunity. Early elimination of the rheumatogenic bacteria may prevent the adaptive immune system from mounting autoimmune responses and minimize transmission of the pathogen. Other vaccines, however, that act against the acute infection by blocking secreted streptococcal virulence 
factors but do not evoke bactericidal immune responses, may fail to protect against ARF. In the absence of pre-existing bactericidal immunity, prolonged exposure of the infecting streptococcus to the adaptive immune system may provoke rheumatogenic autoimmune responses.

Some of the antigens that confer satisfactory protective immunity are known or suspected rheumatogenic factors. This is another obstacle in the development of streptococcal vaccines. Some of the vaccines exploit the immune responses against $M$ protein (see $M$ protein-based vaccines) that protect humans against reinfection with streptococci of the same or a cross-reacting $\mathrm{M}$ type. ${ }^{104-106}$ Notably, after a vaccination trial with a crude preparation of M3, three out of 21 human vaccinees developed ARF or ARF-like symptoms. ${ }^{107}$ Although it cannot be excluded that other streptococcal factors in the vaccine preparation were involved in causing these side effects, it is most likely that the collagen-binding PARF motif in $\mathrm{M}^{43,82}$ was the triggering factor. M5, M6, and M19 do not contain a PARF motif, but do have rheumatogenic structures that exert molecular mimicry. Design of a safe ARF vaccine will use the antigens that induce the desired protective response and omit the structures that induce autoimmunity, which in case of the $\mathrm{M}$ protein reside on the same molecule.

The development of $S$. pyogenes vaccines is also hampered by the lack of suitable animal models with sufficient prediction accuracy regarding vaccine efficacy in humans. The deficits of existing animal models are explained with the specificity of $S$. pyogenes for the human host and resulting shortcomings in mimicking the colonization and pathogenesis observed in humans. ${ }^{108,109}$ These deficits of animal models also affect the risk assessment for autoimmune complications caused by streptococcal vaccines, which is an important issue. Suitable animal models that fully reflect the underlying host factors and the pathogenesis of ARF would be required. However, given the potential complexity of this immune disorder, such models thus far seem to be out of reach. Therefore, available data from trials on humans as well as data from natural streptococcal infections and their sequelae in humans are of utmost importance for research on $S$. pyogenes vaccines.

\section{Vaccine development}

During the last decades a variety of potential vaccine antigens such as M protein derivatives, C5a peptidase, group A carbohydrate, streptococcal fibronectin binding proteins SfbI and FbaA, and many other streptococcal products have been under investigation. The current status of $S$. pyogenes vaccine development, in general, has been recently described by others. ${ }^{108,109}$
Herein, a subjective selection of promising vaccine candidates with respect to prevention of ARF/RHD and safety regarding immunological side effects is discussed (Table 1).

\section{Non-M protein vaccines Group A carbohydrate}

As indicated by its alias "group A Streptococcus", S. pyogenes carries carbohydrate antigens of the serological Lancefield group A. ${ }^{110}$ Immunization with the group A carbohydrate promises $100 \%$ emm type coverage as it is a component of all known $S$. pyogenes strains. Human antibody titers against the group A carbohydrate increase with age and the antibodies promote phagocytosis of $S$. pyogenes of various genotypes. ${ }^{111}$ Moreover, increased antibody titers against group A carbohydrate correlate with absence of $S$. pyogenes colonization in healthy children. ${ }^{64}$ Anti-group A carbohydrate antibodies raised in rabbits provided passive protection in a mouse challenge model and when mice were immunized with group A carbohydrate conjugated to tetanus toxoid, using alum as adjuvant, the animals were protected from death when challenged with $S$. pyogenes strains of two different M types. Oral colonization of the immunized mice by an intranasally applied M3 isolate was also reduced. ${ }^{64}$ Based on these data, the group A carbohydrate appears to be a suitable vaccine candidate. However, as described above, the streptococcal group A carbohydrate may be a rheumatogenic factor of streptococci because immune responses against this antigen may cross-react with human tissue. ${ }^{42,47,48}$ To investigate the potential of group A carbohydrate to trigger autoimmunity, rabbits were immunized with the tetanus toxoid conjugate vaccine and Freund's adjuvant. Neither immunohistological experiments on human tissues, nor enzyme-linked immunosorbent assays with suitable mammalian proteins revealed cross-reactivity with human antigens in the antisera of the immunized rabbits. ${ }^{64}$ Despite these encouraging results, more studies are needed to assess the safety of this vaccine.

\section{C5a peptidase}

Streptococcal C5a peptidase A (SCPA) is a $130 \mathrm{kDa}$ sortase-anchored surface protein of $S$. pyogenes. It cleaves the anaphylatoxin $\mathrm{C} 5 \mathrm{a}$ of the complement cascade, thereby acting as an anti-phagocytic factor. ${ }^{112,113}$ Moreover, SCPA mediates internalization of $S$. pyogenes by epithelial cells. ${ }^{114}$ An SCPA-deficient mutant of S. pyogenes was cleared more rapidly in mouse models of subdermal and nasopharyngeal infection than the isogenic wild-type strain that expressed SCPA, indicating that SCPA is important for streptococcal virulence. ${ }^{115}$ Homologous C5ase enzymes are also produced 
by groups B, C, and $\mathrm{G}$ streptococci. ${ }^{116}$ For instance, the amino acid sequence of SCPB is $95 \%-98 \%$ identical to SCPA. Thus, an SCPA vaccine may provide cross-protection against infections with other pathogenic $\beta$-hemolytic streptococci. ${ }^{117}$ Following intranasal application of a non-adjuvant inactive variant of SCPA, mice produced strong serum immunoglobulin $\mathrm{A}$ and immunoglobulin $\mathrm{M}$ responses and SCPA-specific immunoglobulin A in saliva. ${ }^{118}$ Immunized animals cleared $S$. pyogenes more rapidly than the control group and crossprotection across four different $\mathrm{M}$ serotypes was observed. An injectable, adjuvant formulation of SCPA induced high titers of SCPA-specific serum immunoglobulin $\mathrm{G}$ in immunized mice, which also cleared intranasally inoculated M1 or M49 S. pyogenes more efficiently than the control mice. ${ }^{119}$ A SCPA vaccine could cover the great majority of $S$. pyogenes strains as SCPA is carried by most - if not all isolates. ${ }^{120}$ Interestingly, SCPA has not yet been implicated in the induction of autoimmunity.

\section{Streptococcal protective antigen (Spa)}

As indicated by its name, Spa is capable of inducing protective immune responses and production of bactericidal antibodies in mice. Located on the streptococcal surface, it serves as a virulence factor that acts against phagocytosis. Spa or Spa-like proteins were detected on the surface of 25 out of 70 tested $S$. pyogenes serotypes, suggesting a considerable coverage of a potential Spa vaccine. ${ }^{121}$ In vitro opsonization experiments suggest that immune responses against Spa from M18 may also protect against $S$. pyogenes of M3 and M28. ${ }^{122}$ An N-terminal fragment of Spa is a component of the $M$ protein-based vaccine StreptAvax ${ }^{\mathrm{TM}}$ (ID Biomedical Corporation, Laval, QC, Canada), which has completed a Phase I clinical trial (see Multivalent type-specific M protein vaccine). ${ }^{123} \mathrm{Up}$ to $95 \%$ identity to M-like protein of $S$. equi subsp. zooepidemicus, prediction of a long central coiled-coil region in Spa by Paircoils2 (data not shown), and a C-terminal sortase-dependent cell wall anchoring domain indicate that Spa is an M-like protein.

\section{Superantigen vaccines}

Inactive variants of superantigen pyrogenic exotoxin $\mathrm{A}$ and $\mathrm{C}$ evoked neutralizing antibody responses against these toxins. Immunization with these toxoids protected rabbits that were challenged with the respective isolated superantigen in models of streptococcal toxic shock syndrome. ${ }^{124,125}$ During streptococcal infection, immune responses against superantigen pyrogenic exotoxin $\mathrm{A}$ and $\mathrm{C}$ may protect from the toxic effects of the secreted superantigens, but may not be bactericidal. As the role of superantigens in the pathogenesis of ARF/RHD remains unclear, their value as antigens for a vaccine against these sequelae is questionable.

\section{$M$ protein-based vaccines}

The $\mathrm{M}$ protein is a promising vaccine candidate both because it is an abundant protein on all $S$. pyogenes bacteria that infect humans and because it elicits a protective immune response after natural infection or vaccination. ${ }^{106,123,126,127}$ However, developers of $\mathrm{M}$ protein-based vaccines have to cope with two major difficulties. One is the vast variety of serologically distinct $M$ types, ensuing from the hypervariability in the N-terminal sequence of the M protein. Another is the implication of $\mathrm{M}$ proteins as triggering factors in ARF pathogenesis. ${ }^{7,59}$

Despite these hurdles, the development of M protein-based vaccines has made impressive progress. M protein-based vaccines are among the few that have been tested in humans and have undergone clinical trials. ${ }^{108,109,123}$ In early studies, immunization of humans with purified full-length M1, M3, or M12 induced type-specific titers and reduced the colonization of the vaccinees by S. pyogenes. ${ }^{128-130}$ Purified M proteins were better tolerated by adult volunteers than earlier whole-cell vaccines. However, a trial with partially purified M3 raised serious concerns about the safety of full-length $\mathrm{M}$ protein vaccines in children. While reinfection of the vaccinated children with $S$. pyogenes was markedly reduced, it was associated with a tenfold higher incidence of ARF as compared to the control group. ${ }^{107}$ Considering the ability of $\mathrm{M}$ proteins to trigger autoimmunity ${ }^{7,59}$ the most likely explanation for the immunological complications after immunization with full-length M3 are the rheumatogenic properties of this molecule. Notably, none of the vaccinees was reinfected by $M$ type 3. Perhaps reinfection exerts co-stimuli that are required in M3 proteindependent ARF. After the observation of side effects, trials with full-length $\mathrm{M}$ proteins have ceased, but a comprehensive knowledge about the rheumatogenic motifs and an elaborated antigen design may allow the exclusion of the sequence motifs of the $\mathrm{M}$ protein that trigger an autoimmune disease and to make use of the epitopes that evoke protective responses.

\section{Multivalent type-specific $M$ protein vaccine}

An obvious approach for minimizing the risk of inducing autoimmune disease by an $\mathrm{M}$ protein vaccine is to separate the desired antigenic parts of the molecule that evoke protective responses from the ones that trigger autoimmunity. Most of the motifs that have been implicated in molecular mimicry are located between the A- and C-repeat region of M protein. ${ }^{131}$ 
Therefore, current approaches to $\mathrm{M}$ protein-based vaccines are focused on the more N-terminal and C-terminal parts of this molecule. ${ }^{106,108}$ However, PARF motifs are located in the N-terminal hypervariable region of collagen binding $\mathrm{M}$ proteins (Figure 2). ${ }^{82}$ Natural immunity against $S$. pyogenes infections increases with age and protects against reinfection with streptococci of the same or a cross-reacting emm type, thus is type specific. ${ }^{103,126,127}$ The N-terminal part of the M protein contributes to type-specific immunity as protective immune responses are directed against this hypervariable part of the bacterial surface protein. ${ }^{132}$ A prototype hexavalent vaccine that combined short N-terminal sequences of six different emm types in tandem arrangement and a further developed 26-valent vaccine named StreptAvax underwent preclinical and Phase I and II clinical trials. ${ }^{108}$ The vaccines were well-tolerated by adult volunteers with frequent but mild and self-limited adverse reactions. Neither ARF nor acute post-streptococcal glomerulonephritis was diagnosed after vaccination. ${ }^{123}$ Immunization with StreptAvax increased human serum antibody titers against all of the emm types that were included in the vaccine. Moreover, the sera were bactericidal against all of these emm types. StreptAvax was designed to cover the predominant emm types in invasive infections and pediatric pharyngitis as identified by a study in the USA. Types that were found associated with ARF were also included. Furthermore, StreptAvax contains the N-terminal sequence of Spa as a 27 th antigen (see Streptococcal protective antigen). The Phase I clinical trial proved the efficacy of StreptAvax against the targeted emm types. ${ }^{123}$ With the aim of increasing the coverage within the plethora of different emm types, a 30-valent vaccine has been designed and subjected to preclinical tests. Immunized rabbits developed increased titers of bactericidal antibodies against the $30 \mathrm{emm}$ types that were targeted by the vaccine. Beyond that, bactericidal cross-reactivity with 24 out of 40 non-vaccine emm types was observed, indicating that the actual emm type coverage of multivalent $\mathrm{M}$ protein vaccines (actual coverage) is much higher than the rate of the vaccine emm types in the respective $S$. pyogenes population (estimated emm type coverage). ${ }^{104}$ Still, in light of low emm type coverage rates in regions with a high prevalence of ARF/RHD, ${ }^{101,104}$ the 30 -valent type-specific vaccine in its current version may not be suitable to combat these diseases in their geographic "hot spots". Emm type distribution is known to differ largely between geographic regions and over time (see The plethora of $S$. pyogenes emm types, their geographic distribution, and consequences for vaccine development)..$^{82,85,99,101-103}$ Thus, type-specific M protein vaccines would have to be tailored individually for different geographic regions and regularly redeveloped to follow the rapid changes in the emm type distribution.

A risk of introducing unknown rheumatogenic factors into the vaccine would go along with the continuous changes in the antigen composition of type-specific $M$ protein vaccines. For instance, some types of $\mathrm{M}$ proteins are predicted to form N-terminal coiled-coils (Figure 3). Unfortunately, too little is currently known to exclude the risk of molecular mimicry by such N-terminal type-specific fragments. An already existing risk factor is the PARF motif in the emm3-specific part of StreptAvax and of the 30-valent vaccine. As part of an intact dimeric $M$ protein, this motif binds collagen and triggers autoimmunity against this host protein (see Role of collagen binding and the peptide associated with rheumatic fever [PARF] in ARF and RHD). However, recent findings indicate that the presence of a PARF motif alone may not be sufficient for collagen binding and may depend on the integrity of the motif within the $\mathrm{M}$ protein structure. ${ }^{82}$ To date, it is not published whether the emm3-containing antigen of StreptAvax is binding to collagen or if StreptAvax has been tested for the induction of collagen autoimmunity in an established assay.

The Phase I clinical trial did not indicate a rheumatogenic potential of StreptAvax in 30 adult volunteers ${ }^{123}$ despite the presence of PARF in one of the vaccine antigens. However, the risk assessment remains difficult. The ARF vaccine needs to be safe for use in children who might react differently to adults. ARF is rare in early childhood and most frequent in late childhood before adolescence. Episodes of ARF rarely occur in adults. Notably, immune complications that were noted in three out of 21 children after vaccination with full-length M3, which is a frequent PARF-positive M type, occurred only after reinfection ${ }^{\mathrm{a}}$ by streptococci. ${ }^{107}$ Thus, reinfection with streptococci after vaccination could be critical for occurrence of the autoimmune side effects. The rates of streptococcal reinfection in adult volunteers under the Phase I clinical trial with StreptAvax are not known to the authors, but streptococcal sore throat is known to be more frequent in children as compared to adults. More data are expected from the Phase II clinical trial with StreptAvax, but are not yet available.

As M3 is one of the most frequent $M$ types in the world ${ }^{85}$ and a trigger of $\mathrm{ARF},{ }^{44,131}$ it needs to be targeted by $S$. pyogenes vaccines. However, there is a remaining risk of evoking autoimmune disease by the PARF motif in the emm3-specific part of vaccine antigens. The development of multivalent type-specific M protein vaccines will benefit from 
A

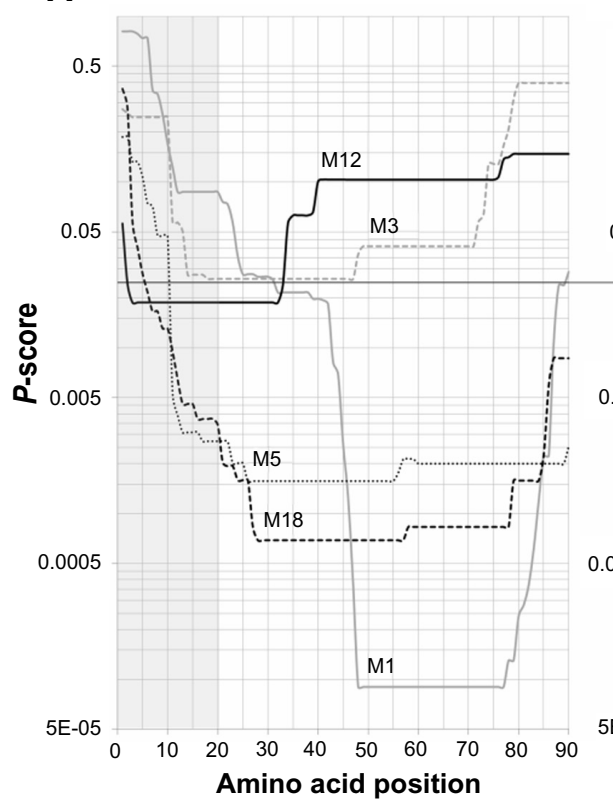

B

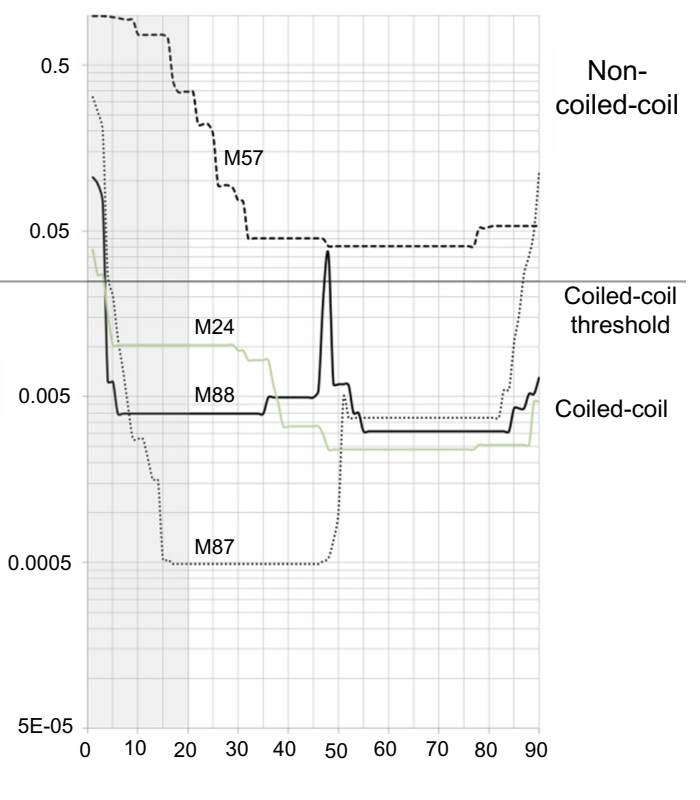

Figure 3 Coiled-coil prediction for N-terminal sequences of M proteins. Coiled-coil structure prediction with Paircoil2 (http://groups.csail.mit.edu/cb/paircoil2/paircoil2. html) for the $\mathrm{N}$-terminal sequences of selected $M$ proteins is given as $P$-scores versus amino acid position. The cleavage site of the signal peptidase was predicted with SignalP (http://www.cbs.dtu.dk/services/SignalP/) to determine the sequence of the first 90 amino acids of the mature $M$ protein. M types are indicated above the curves. Gray areas highlight the first 20 amino acids on the $M$ protein. A black line indicates the threshold value for coiled-coil prediction. P-scores $<0.025$ indicate a predicted coiled-coil structure. (A) M proteins that are frequent worldwide and were found associated with acute rheumatic fever. (B) Examples for M proteins without coiled-coil regions (M57) or with extended (M24, M87, M88) coiled-coil regions in the N-terminal type-specific sequence.

the growing knowledge on PARF and other streptococcal factors that cause ARF. This knowledge will help to reduce the risk of side effects, thus the costs of development of the type-specific $M$ protein vaccines. This is of particular importance since continuous adaptation of these vaccines to the region specific and dynamic emm type distribution will be necessary.

\section{CCR vaccines}

Using conserved regions of the M protein in a streptococcal vaccine promises higher cross-protection, thus higher emm type coverage than type-specific vaccines. This has led the conserved CCR into the limelight of $S$. pyogenes vaccine development. Although antibodies against this region are not opsonic, ${ }^{133,134}$ immunization with peptides of the CCR protected mice that were challenged with $S$. pyogenes of a different $\mathrm{M}$ type. ${ }^{133,135,136}$

Identification of the immunodominant T- and B-cell epitopes in the CCR of M5 yielded a 55 amino acid vaccine antigen named StreptInCor. ${ }^{137,138}$ In preclinical experiments, immunization with StreptInCor evoked immune responses in mice that cross-protected from lethal infection with $S$. pyogenes of M1. ${ }^{139,140}$ No signs of molecular mimicry or autoimmunity were observed in these preclinical experiments, indicating that StreptInCor could be a safe vaccine antigen.
In addition, a 20 amino acid peptide within the CCR, named p145, has been identified as a potential vaccine antigen. ${ }^{141}$ A high proportion of people living in areas with high prevalence rates of ARF and RHD had increased titers of antibodies against p145 in their sera. ${ }^{142}$ Subsequently, a minimal B-cell epitope was identified within p145 that did not contain any T-cell epitopes. ${ }^{143}$ Based on the theory that rheumatic valvulitis is predominantly T-cell mediated, ${ }^{144-146}$ the use of such an antigen in a vaccine is thought to minimize the risk of inducing autoimmunity. ${ }^{143}$ The minimal T-cell epitope is part of peptide J14, a derivative of p145. J14 carries heterologous flanking regions to retain the $\alpha$-helical structure of the internal $\mathrm{M}$ protein epitope $\mathrm{J}_{14}$. Vaccination with $\mathrm{J} 14$ conjugates protected mice from intraperitoneal and intranasal challenge and led to production of bactericidal antibodies. ${ }^{106,141,143,147-149}$

To increase the serotype coverage, common $\mathrm{J} 14_{\mathrm{i}}$ variants were identified that represent 77 different emm types. Antigen SV1 that was composed of seven $\mathrm{J}_{1} 4_{\mathrm{i}}$ modules of five $\mathrm{J} 14_{\mathrm{i}}$ variants evoked production of bactericidal antibodies in mice that killed heterologous $S$. pyogenes serotypes in vitro. ${ }^{106}$ As for the multivalent type-specific vaccines, the available data do not yet exclude autoimmune side effects, despite promising preclinical testing. The strength of the CCR-based vaccine is the use of less and similar antigen modules to cover the variety of $S$. pyogenes serotypes. This lowers the risk of including 
rheumatogenic factors in the initial design and potentially required redesign of a multivalent CCR-based vaccine.

\section{Modern approaches in the search for alternative vaccine candidates}

Considering the difficulties described in the Vaccine development section, the development of S. pyogenes vaccines could benefit from the identification of novel vaccine candidates. The last decades have witnessed a number of technological advances that can be exploited in the search for new effective antigens. Bioinformatics reveal the complete inventory of potential vaccine candidates by analyzing whole genome sequences of $S$. pyogenes. Several bioinformatics tools are available to predict B-cell epitopes, signal peptides for extracellular secretion, transmembrane regions, and sortase-dependent cell wall anchoring motifs of $S$. pyogenes proteins. This is used to identify the potential surface-located antigens, suitable for use in a vaccine. ${ }^{150-152}$ Lei et al compared the S. pyogenes genomes of six different emm types, thereby identifying highly conserved putative lipoproteins as vaccine candidates. These proteins were immunogenic during human and animal infections. ${ }^{153}$ Transcriptome or proteome data are used to limit the variety of potential surface molecules to the ones that are actually synthesized or present under relevant conditions. The use of genome, transcriptome, and proteome data for identification of vaccine antigens is known as "reverse vaccinology"154 and has led to the discovery of new candidate antigens for S. pyogenes vaccines. ${ }^{150-152,155}$ Reverse vaccinology reduces the time and costs for the identification of vaccine candidates and can be successful where conventional approaches have failed.

\section{Conclusion}

Particularly in less developed regions of the world, RHD remains the major cardiologic disease in the young and middle age population despite the availability of effective antibiotics to treat the causative infections and ARF. Thus, an effective vaccine against the causative infection is a valuable alternative to meet this continued threat to human health that has declined in the last few decades but is still far from being eliminated. Several vaccine candidates have been identified in the past and modern approaches of reverse vaccinology have identified more. Despite early and severe setbacks in the development of M protein-based vaccines, they have remained among the most promising candidates. Two major obstacles lie in front of the aim of a safe and effective $S$. pyogenes vaccine. One is the vast serological diversity of $S$. pyogenes that is difficult to cover even with multivalent vaccines. The other one is the difficulty to foresee immunological side effects of $\mathrm{M}$ protein-based vaccines. This requires a more comprehensive knowledge of the streptococcal triggers of autoimmunity and animal models with sufficient predictive power. Both are not yet satisfactory. Last but not least, evidence is accumulating that SDSE is rheumatogenic and may also have to be targeted by the ARF vaccine. Taken together, the growing knowledge on the diversity of rheumatogenic streptococci and the streptococcal triggers of autoimmunity could guide the development of safe and effective vaccines against ARF.

\section{Acknowledgments}

The authors thank Dr Andrew Oxley for proofreading and linguistic corrections. AS acknowledges Alexander von Humboldt Foundation, Germany for financial support.

\section{Disclosure}

The Helmholtz Centre for Infection Research holds patent WO 2007/140953 A1 (peptide associated with rheumatic fever [PARF] and its use as a diagnostic marker). The authors have no other conflicts of interest in this work.

\section{References}

1. Chhatwal GS, Graham RM. Streptococcal diseases. In: Encyclopedia of Public Health 2008. San Diego: Academic Press; 2008:231-241.

2. Carapetis JR, Steer AC, Mulholland EK, Weber M. The global burden of group A streptococcal diseases. Lancet Infect Dis. 2005;5(11): 685-694.

3. Marijon E, Mirabel M, Celermajer DS, Jouven X. Rheumatic heart disease. Lancet. 2012;379(9819):953-964.

4. Tandon R, Sharma M, Chandrashekhar Y, Kotb M, Yacoub MH, Narula J. Revisiting the pathogenesis of rheumatic fever and carditis. Nat Rev Cardiol. 2013;10(3):171-177.

5. Wannamaker LW. The chain that links the heart to the throat. Circulation. 1973;48(1):9-18

6. Haidan A, Talay SR, Rohde M, Sriprakash KS, Currie BJ, Chhatwal GS. Pharyngeal carriage of group $\mathrm{C}$ and group $\mathrm{G}$ streptococci and acute rheumatic fever in an Aboriginal population. Lancet. 2000;356(9236):1167-1169.

7. Nitsche-Schmitz DP, Chhatwal GS. Host-pathogen interactions in streptococcal immune sequelae. Curr Top Microbiol Immunol. 2013;368:155-171.

8. Guilherme L, Weidebach W, Kiss MH, Snitcowsky R, Kalil J. Association of human leukocyte class II antigens with rheumatic fever or rheumatic heart disease in a Brazilian population. Circulation. 1991;83(6):1995-1998.

9. Ozkan M, Carin M, Sonmez G, Senocak M, Ozdemir M, Yakut C. HLA antigens in Turkish race with rheumatic heart disease [see comment]. Circulation. 1993;87(6):1974-1978.

10. Weidebach W, Goldberg AC, Chiarella JM, et al. HLA class II antigens in rheumatic fever. Analysis of the DR locus by restriction fragmentlength polymorphism and oligotyping. Hum Immunol. 1994;40(4): 253-258.

11. Guedez Y, Kotby A, El-Demellawy M, et al. HLA class II associations with rheumatic heart disease are more evident and consistent among clinically homogeneous patients. Circulation. 1999;99(21): 2784-2790. 
12. Visentainer JE, Pereira FC, Dalalio MM, Tsuneto LT, Donadio PR, Moliterno RA. Association of HLA-DR7 with rheumatic fever in the Brazilian population. J Rheumatol. 2000;27(6):1518-1520.

13. Ayoub EM, Barrett DJ, Maclaren NK, Krischer JP. Association of class II human histocompatibility leukocyte antigens with rheumatic fever. J Clin Invest. 1986;77(6):2019-2026.

14. Rajapakse CN, Halim K, Al-Orainey I, Al-Nozha M, Al-Aska AK. A genetic marker for rheumatic heart disease. Br Heart J. 1987;58(6): 659-662.

15. Stanevicha V, Eglite J, Zavadska D, Sochnevs A, Shantere R, Gardovska D. HLA class II DR and DQ genotypes and haplotypes associated with rheumatic fever among a clinically homogeneous patient population of Latvian children. Arthritis Res Ther. 2007;9(3):R58.

16. Stanevicha V, Eglite J, Sochnevs A, Gardovska D, Zavadska D, Shantere R. HLA class II associations with rheumatic heart disease among clinically homogeneous patients in children in Latvia. Arthritis Res Ther. 2003;5(6):R340-R346.

17. Koyanagi T, Koga Y, Nishi H, et al. DNA typing of HLA class II genes in Japanese patients with rheumatic heart disease. J Mol Cell Cardiol. 1996;28(6):1349-1353.

18. Hernandez-Pacheco G, Aguilar-Garcia J, Flores-Dominguez C, et al. MHC class II alleles in Mexican patients with rheumatic heart disease. Int J Cardiol. 2003;92(1):49-54.

19. Keitzer R. [Acute rheumatic fever (ARF) and poststreptococcal reactive arthritis (PSRA) - an update]. Z Rheumatol. 2005;64(5):295-307. German.

20. Cunningham MW. Pathogenesis of group A streptococcal infections. Clin Microbiol Rev. 2000;13(3):470-511.

21. Pavone P, Parano E, Rizzo R, Trifiletti RR. Autoimmune neuropsychiatric disorders associated with streptococcal infection: Sydenham chorea, PANDAS, and PANDAS variants. J Child Neurol. 2006;21(9): 727-736.

22. de Alvarenga PG, Hounie AG, Miguel EC. The role of group A $\beta$-hemolytic streptococcal infection in neuropsychiatric disorders. Pediatrics. 2008;122(5):1157; author reply 1157-1158.

23. Kurlan R, Johnson D, Kaplan EL; Tourette Syndrome Study Group. Streptococcal infection and exacerbations of childhood tics and obsessive-compulsive symptoms: a prospective blinded cohort study. Pediatrics. 2008;121(6):1188-1197.

24. Kaplan MH, Bolande R, Rakita L, Blair J. Presence of bound immunoglobulins and complement in the myocardium in acute rheumatic fever. Association with cardiac failure. N Engl J Med. 1964;271: 637-645.

25. Guilherme L, Kalil J, Cunningham M. Molecular mimicry in the autoimmune pathogenesis of rheumatic heart disease. Autoimmunity. 2006;39(1):31-39.

26. Cunningham MW. Autoimmunity and molecular mimicry in the pathogenesis of post-streptococcal heart disease. Front Biosci. 2003;8: s533-s543.

27. Roberts S, Kosanke S, Terrence Dunn S, Jankelow D, Duran CM, Cunningham MW. Pathogenic mechanisms in rheumatic carditis: focus on valvular endothelium. J Infect Dis. 2001;183(3):507-511.

28. Hunt DF, Henderson RA, Shabanowitz J, et al. Characterization of peptides bound to the class I MHC molecule HLA-A2.1 by mass spectrometry. Science. 1992;255(5049):1261-1263.

29. Miller SD, Vanderlugt CL, Begolka WS, et al. Persistent infection with Theiler's virus leads to CNS autoimmunity via epitope spreading. Nat Med. 1997;3(10):1133-1136.

30. Lehmann PV, Forsthuber T, Miller A, Sercarz EE. Spreading of T-cell autoimmunity to cryptic determinants of an autoantigen. Nature. 1992;358(6382):155-157.

31. Lehmann PV, Targoni OS, Forsthuber TG. Shifting T-cell activation thresholds in autoimmunity and determinant spreading. Immunol Rev. 1998;164:53-61.

32. Kotb M. Bacterial pyrogenic exotoxins as superantigens. Clin Microbiol Rev. 1995;8(3):411-426.
33. Stevens DL, Tanner MH, Winship J, et al. Severe group A streptococcal infections associated with a toxic shock-like syndrome and scarlet fever toxin A. N Engl J Med. 1989;321(1):1-7.

34. Yu CE, Ferretti JJ. Molecular epidemiologic analysis of the type A streptococcal exotoxin (erythrogenic toxin) gene (speA) in clinical Streptococcus pyogenes strains. Infect Immun. 1989;57(12): 3715-3719.

35. Eriksson BK, Andersson J, Holm SE, Norgren M. Invasive group A streptococcal infections: T1M1 isolates expressing pyrogenic exotoxins $\mathrm{A}$ and $\mathrm{B}$ in combination with selective lack of toxin-neutralizing antibodies are associated with increased risk of streptococcal toxic shock syndrome. J Infect Dis. 1999;180(2):410-418.

36. Sriskandan S, Moyes D, Cohen J. Detection of circulating bacterial superantigen and lymphotoxin- $\alpha$ in patients with streptococcal toxicshock syndrome. Lancet. 1996;348(9037):1315-1316.

37. Proft T, Fraser JD. Bacterial superantigens. Clin Exp Immunol. 2003;133(3):299-306.

38. Brocke S, Gaur A, Piercy C, et al. Induction of relapsing paralysis in experimental autoimmune encephalomyelitis by bacterial superantigen. Nature. 1993;365(6447):642-644.

39. Cole BC, Griffiths MM. Triggering and exacerbation of autoimmune arthritis by the Mycoplasma arthritidis superantigen MAM. Arthritis Rheum. 1993;36(7):994-1002.

40. Carapetis JR, McDonald M, Wilson NJ. Acute rheumatic fever. Lancet. 2005;366(9480):155-168.

41. Tontsch D, Pankuweit S, Maisch B. Autoantibodies in the sera of patients with rheumatic heart disease: characterization of myocardial antigens by two-dimensional immunoblotting and $\mathrm{N}$-terminal sequence analysis. Clin Exp Immunol. 2000;121(2):270-274.

42. Goldstein I, Rebeyrotte P, Parlebas J, Halpern B. Isolation from heart valves of glycopeptides which share immunological properties with Streptococcus haemolyticus group A polysaccharides. Nature. 1968;219(5156):866-868.

43. Dinkla K, Nitsche-Schmitz DP, Barroso V, et al. Identification of a streptococcal octapeptide motif involved in acute rheumatic fever. J Biol Chem. 2007;282(26):18686-18693.

44. Dinkla K, Rohde M, Jansen WT, Kaplan EL, Chhatwal GS, Talay SR. Rheumatic fever-associated Streptococcus pyogenes isolates aggregate collagen. J Clin Invest. 2003;111(12):1905-1912.

45. Kaplan MH, Suchy ML. Immunologic relation of streptococcal and tissue antigens. II. Cross-reaction of antisera to mammalian heart tissue with a cell wall constituent of certain strains of group A streptococci. J Exp Med. 1964;119:643-650.

46. Zabriskie JB, Freimer EH. An immunological relationship between the group A streptococcus and mammalian muscle. J Exp Med. 1966;124(4):661-678.

47. Dudding BA, Ayoub EM. Persistence of streptococcal group A antibody in patients with rheumatic valvular disease. J Exp Med. 1968;128(5): 1081-1098.

48. Adderson EE, Shikhman AR, Ward KE, Cunningham MW. Molecular analysis of polyreactive monoclonal antibodies from rheumatic carditis: human anti-N-acetylglucosamine/anti-myosin antibody $\mathrm{V}$ region genes. J Immunol. 1998;161(4):2020-2031.

49. Fischetti VA. Streptococcal M protein: molecular design and biological behavior. Clin Microbiol Rev. 1989;2(3):285-314.

50. Nitsche-Schmitz DP, Rohde M, Chhatwal GS. Invasion mechanisms of Gram-positive pathogenic cocci. Thromb Haemost. 2007;98(3): $488-496$.

51. Oehmcke S, Shannon O, Mörgelin M, Herwald H. Streptococcal $\mathrm{M}$ proteins and their role as virulence determinants. Clin Chim Acta. 2010;411(17-18):1172-1180.

52. Reissmann S, Friedrichs C, Rajkumari R, et al. Contribution of Streptococcus anginosus to infections caused by groups $\mathrm{C}$ and $\mathrm{G}$ streptococci, southern India. Emerg Infect Dis. 2010;16(4):656-663.

53. Facklam R, Beall B, Efstratiou A, et al. Emm typing and validation of provisional M types for group A streptococci. Emerg Infect Dis. $1999 ; 5(2): 247-253$ 
54. Phillips GN Jr, Flicker PF, Cohen C, Manjula BN, Fischetti VA. Streptococcal M protein: $\alpha$-helical coiled-coil structure and arrangement on the cell surface. Proc Natl Acad Sci U S A. 1981;78(8): 4689-4693.

55. Fischetti VA, Pancholi V, Schneewind O. Conservation of a hexapeptide sequence in the anchor region of surface proteins from Gram-positive cocci. Mol Microbiol. 1990;4(9):1603-1605.

56. Klebsiella and ankylosing spondylitis - molecular mimicry? Lancet. 1979;1(8124):1012-1013.

57. Blank M, Barzilai O, Shoenfeld Y. Molecular mimicry and auto-immunity. Clin Rev Allergy Immunol. 2007;32(1):111-118.

58. Guilherme L, Kalil J. Rheumatic fever and rheumatic heart disease: cellular mechanisms leading autoimmune reactivity and disease. J Clin Immunol. 2010;30(1):17-23.

59. Cunningham MW. Streptococcus and rheumatic fever. Curr Opin Rheumatol. 2012;24(4):408-416.

60. McCormack JM, Crossley CA, Ayoub EM, Harley JB, Cunningham MW. Poststreptococcal anti-myosin antibody idiotype associated with systemic lupus erythematosus and Sjogren's syndrome. J Infect Dis. 1993;168(4):915-921.

61. Zabriskie JB. Mimetic relationships between group A streptococci and mammalian tissues. Adv Immunol. 1967;7:147-188.

62. Cunningham MW, Krisher K, Graves DC. Murine monoclonal antibodies reactive with human heart and group A streptococcal membrane antigens. Infect Immun. 1984;46(1):34-41.

63. Cunningham MW, Russell SM. Study of heart-reactive antibody in antisera and hybridoma culture fluids against group A streptococci. Infect Immun. 1983;42(2):531-538.

64. Sabharwal H, Michon F, Nelson D, et al. Group A streptococcus (GAS) carbohydrate as an immunogen for protection against GAS infection. J Infect Dis. 2006;193(1):129-135.

65. Bronze MS, Beachey EH, Dale JB. Protective and heart-crossreactive epitopes located within the NH2 terminus of type 19 streptococcal M protein. J Exp Med. 1988;167(6):1849-1859.

66. Cunningham MW, McCormack JM, Fenderson PG, Ho MK, Beachey EH, Dale JB. Human and murine antibodies cross-reactive with streptococcal M protein and myosin recognize the sequence GLN-LYSSER-LYS-GLN in M protein. J Immunol. 1989;143(8):2677-2683.

67. Dale JB, Beachey EH. Epitopes of streptococcal M proteins shared with cardiac myosin. J Exp Med. 1985;162(2):583-591.

68. Dale JB, Beachey EH. Multiple, heart-cross-reactive epitopes of streptococcal M proteins. J Exp Med. 1985;161(1):113-122.

69. Dale JB, Beachey EH. Sequence of myosin-crossreactive epitopes of streptococcal M protein. J Exp Med. 1986;164(5):1785-1790.

70. Fae KC, da Silva DD, Oshiro SE, et al. Mimicry in recognition of cardiac myosin peptides by heart-intralesional $\mathrm{T}$ cell clones from rheumatic heart disease. J Immunol. 2006;176(9):5662-5670.

71. Alehan D, Ayabakan C, Hallioglu O. Role of serum cardiac troponin T in the diagnosis of acute rheumatic fever and rheumatic carditis. Heart. 2004;90(6):689-690.

72. Gupta M, Lent RW, Kaplan EL, Zabriskie JB. Serum cardiac troponin I in acute rheumatic fever. Am J Cardiol. 2002;89(6):779-782.

73. Galvin JE, Hemric ME, Ward K, Cunningham MW. Cytotoxic mAb from rheumatic carditis recognizes heart valves and laminin. J Clin Invest. 2000;106(2):217-224.

74. Veasy LG, Tani LY, Daly JA, et al. Temporal association of the appearance of mucoid strains of Streptococcus pyogenes with a continuing high incidence of rheumatic fever in Utah. Pediatrics. 2004;113(3 Pt 1): e168-e172.

75. Smoot JC, Korgenski EK, Daly JA, Veasy LG, Musser JM. Molecular analysis of group A Streptococcus type emm18 isolates temporally associated with acute rheumatic fever outbreaks in Salt Lake City, Utah. J Clin Microbiol. 2002;40(5):1805-1810.

76. Vos Q, Lees A, Wu ZQ, Snapper CM, Mond JJ. B-cell activation by T-cell-independent type 2 antigens as an integral part of the humoral immune response to pathogenic microorganisms. Immunol Rev. 2000;176:154-170.
77. Chong BF, Blank LM, McLaughlin R, Nielsen LK. Microbial hyaluronic acid production. Appl Microbiol Biotechnol. 2005;66(4):341-351.

78. Woolcock JB. The capsule of Streptococcus equi. J Gen Microbiol. 1974;85(2):372-375.

79. Duca E, Teodorovici G, Radu C, et al. A new nephritogenic streptococcus. J Hyg (Lond). 1969;67(4):691-698.

80. Barnham M, Thornton TJ, Lange K. Nephritis caused by Streptococcus zooepidemicus (Lancefield group C). Lancet. 1983;1(8331):945-948.

81. Barroso V, Rohde M, Davies MR, et al. Identification of active variants of PARF in human pathogenic group $\mathrm{C}$ and group $\mathrm{G}$ streptococci leads to an amended description of its consensus motif. Int J Med Microbiol. 2009;299(8):547-553.

82. Reissmann S, Gillen CM, Fulde M, et al. Region specific and worldwide distribution of collagen-binding $\mathrm{M}$ proteins with PARF motifs among human pathogenic streptococcal isolates. PLoS One. 2012;7(1):e30122.

83. Nitsche DP, Johansson HM, Frick IM, Mörgelin M. Streptococcal protein FOG, a novel matrix adhesin interacting with collagen I in vivo. J Biol Chem. 2006;281(3):1670-1679.

84. Chan AL, Louie S, Leslie KO, Juarez MM, Albertson TE. Cutting edge issues in Goodpasture's disease. Clin Rev Allergy Immunol. 2011;41(2): 151-162.

85. Steer AC, Law I, Matatolu L, Beall BW, Carapetis JR. Global emm type distribution of group A streptococci: systematic review and implications for vaccine development. Lancet Infect Dis. 2009;9(10):611-616.

86. Bober M, Mörgelin M, Olin AI, von Pawel-Rammingen U, Collin M. The membrane bound LRR lipoprotein Slr, and the cell wall-anchored M1 protein from Streptococcus pyogenes both interact with type I collagen. PLoS One. 2011;6(5):e20345.

87. McCarty M. Nature of rheumatic fever. Circulation. 1956;14(6): 1138-1143.

88. McDonald MI, Towers RJ, Andrews RM, Benger N, Currie BJ, Carapetis JR. Low rates of streptococcal pharyngitis and high rates of pyoderma in Australian aboriginal communities where acute rheumatic fever is hyperendemic. Clin Infect Dis. 2006;43(6):683-689.

89. Broyles LN, Van Beneden C, Beall B, et al. Population-based study of invasive disease due to $\beta$-hemolytic streptococci of groups other than A and B. Clin Infect Dis. 2009;48(6):706-712.

90. Ogunbi O, Fadahunsi HO, Ahmed I, et al. An epidemiological study of rheumatic fever and rheumatic heart disease in Lagos. J Epidemiol Community Health. 1978;32(1):68-71.

91. McDonald M, Currie BJ, Carapetis JR. Acute rheumatic fever: a chink in the chain that links the heart to the throat? Lancet Infect Dis. 2004;4(4):240-245.

92. Simpson WJ, Robbins JC, Cleary PP. Evidence for group A-related $M$ protein genes in human but not animal-associated group $\mathrm{G}$ streptococcal pathogens. Microb Pathog. 1987;3(5):339-350.

93. McDonald M, Towers RJ, Andrews RM, Carapetis JR, Currie BJ. Epidemiology of Streptococcus dysgalactiae subsp. equisimilis in tropical communities, Northern Australia. Emerg Infect Dis. 2007;13(11): $1694-1700$

94. Fittipaldi N, Beres SB, Olsen RJ, et al. Full-genome dissection of an epidemic of severe invasive disease caused by a hypervirulent, recently emerged clone of group A Streptococcus. Am J Pathol. 2012;180(4): $1522-1534$.

95. Beres SB, Carroll RK, Shea PR, et al. Molecular complexity of successive bacterial epidemics deconvoluted by comparative pathogenomics. Proc Natl Acad Sci U S A. 2010;107(9):4371-4376.

96. Protocol for emm typing [webpage on the Internet]. Atlanta, GA: Centers for Disease Control and Prevention; 2008. Available from: http://www.cdc.gov/ncidod/biotech/strep/protocol_emm-type.htm. Accessed April 16, 2014.

97. Musser JM, Shelburne SA 3rd. A decade of molecular pathogenomic analysis of group A Streptococcus. J Clin Invest. 2009;119(9):2455-2463.

98. Cleary PP, Kaplan EL, Handley JP, et al. Clonal basis for resurgence of serious Streptococcus pyogenes disease in the 1980s. Lancet. 1992;339(8792):518-521. 
99. Smeesters PR, McMillan DJ, Sriprakash KS, Georgousakis MM. Differences among group A streptococcus epidemiological landscapes: consequences for M protein-based vaccines? Expert Rev Vaccines. 2009;8(12):1705-1720.

100. Stollerman GH. Rheumatic fever in the 21 st century. Clin Infect Dis. 2001;33(6):806-814.

101. Dey N, McMillan DJ, Yarwood PJ, et al. High diversity of group A Streptococcal emm types in an Indian community: the need to tailor multivalent vaccines. Clin Infect Dis. 2005;40(1):46-51.

102. McDonald MI, Towers RJ, Andrews R, et al. The dynamic nature of group A streptococcal epidemiology in tropical communities with high rates of rheumatic heart disease. Epidemiol Infect. 2008;136(4): 529-539.

103. Kaplan EL, Wotton JT, Johnson DR. Dynamic epidemiology of group A streptococcal serotypes associated with pharyngitis. Lancet. 2001;358(9290):1334-1337.

104. Dale JB, Penfound TA, Chiang EY, Walton WJ. New 30-valent M proteinbased vaccine evokes cross-opsonic antibodies against non-vaccine serotypes of group A streptococci. Vaccine. 2011;29(46):8175-8178.

105. Steer AC, Batzloff MR, Mulholland K, Carapetis JR. Group A streptococcal vaccines: facts versus fantasy. Curr Opin Infect Dis. 2009;22(6):544-552.

106. Bauer MJ, Georgousakis MM, Vu T, et al. Evaluation of novel Streptococcus pyogenes vaccine candidates incorporating multiple conserved sequences from the C-repeat region of the M-protein. Vaccine. 2012;30(12):2197-2205.

107. Massell BF, Honikman LH, Amezcua J. Rheumatic fever following streptococcal vaccination. Report of three cases. JAMA. 1969;207(6): 1115-1119.

108. Dale JB, Fischetti VA, Carapetis JR, et al. Group A streptococcal vaccines: paving a path for accelerated development. Vaccine. 2013;31(Suppl 2):B216-B222.

109. Henningham A, Gillen CM, Walker MJ. Group A streptococcal vaccine candidates: potential for the development of a human vaccine. Curr Top Microbiol Immunol. 2013;368:207-242.

110. Lancefield RC. A serological differentiation of human and other groups of hemolytic streptococci. J Exp Med. 1933;57(4):571-595.

111. Salvadori LG, Blake MS, McCarty M, Tai JY, Zabriskie JB. Group A streptococcus-liposome ELISA antibody titers to group A polysaccharide and opsonophagocytic capabilities of the antibodies. J Infect Dis. 1995;171(3):593-600.

112. O'Connor SP, Cleary PP. In vivo Streptococcus pyogenes C5a peptidase activity: analysis using transposon- and nitrosoguanidineinduced mutants. J Infect Dis. 1987;156(3):495-504.

113. Wexler DE, Chenoweth DE, Cleary PP. Mechanism of action of the group A streptococcal C5a inactivator. Proc Natl Acad Sci U S A. 1985;82(23):8144-8148.

114. Purushothaman SS, Park HS, Cleary PP. Promotion of fibronectin independent invasion by $\mathrm{C} 5 \mathrm{a}$ peptidase into epithelial cells in group A Streptococcus. Indian J Med Res. 2004;119 Suppl:44-47.

115. Ji Y, McLandsborough L, Kondagunta A, Cleary PP. C5a peptidase alters clearance and trafficking of group A streptococci by infected mice. Infect Immun. 1996;64(2):503-510.

116. Cleary PP, Peterson J, Chen C, Nelson C. Virulent human strains of group $\mathrm{G}$ streptococci express a C5a peptidase enzyme similar to that produced by group A streptococci. Infect Immun. 1991;59(7): 2305-2310.

117. Chmouryguina I, Suvorov A, Ferrieri P, Cleary PP. Conservation of the C5a peptidase genes in group A and B streptococci. Infect Immun 1996;64(7):2387-2390.

118. Ji Y, Carlson B, Kondagunta A, Cleary PP. Intranasal immunization with C5a peptidase prevents nasopharyngeal colonization of mice by the group A Streptococcus. Infect Immun. 1997;65(6):2080-2087.

119. Cleary PP, Matsuka YV, Huynh T, Lam H, Olmsted SB. Immunization with $\mathrm{C} 5 \mathrm{a}$ peptidase from either group A or B streptococci enhances clearance of group A streptococci from intranasally infected mice. Vaccine. 2004;22(31-32):4332-4341.
120. Shet A, Kaplan EL, Johnson DR, Cleary PP. Immune response to group A streptococcal C5a peptidase in children: implications for vaccine development. J Infect Dis. 2003;188(6):809-817.

121. Ahmed EA, Penfound TA, Brewer SC, Tennant PA, Chiang EY, Dale JB. Streptococcal protective antigens (Spa): a new family of type-specific proteins of group A streptococci. Eur J Clin Microbiol Infect Dis. 2010;29(1):51-57.

122. Dale JB, Chiang EY, Liu S, Courtney HS, Hasty DL. New protective antigen of group A streptococci. J Clin Invest. 1999;103(9):1261-1268.

123. McNeil SA, Halperin SA, Langley JM, et al. Safety and immunogenicity of 26-valent group A streptococcus vaccine in healthy adult volunteers. Clin Infect Dis. 2005;41(8):1114-1122.

124. Roggiani M, Stoehr JA, Olmsted SB, et al. Toxoids of streptococcal pyrogenic exotoxin A are protective in rabbit models of streptococcal toxic shock syndrome. Infect Immun. 2000;68(9):5011-5017.

125. McCormick JK, Tripp TJ, Olmsted SB, et al. Development of streptococcal pyrogenic exotoxin $\mathrm{C}$ vaccine toxoids that are protective in the rabbit model of toxic shock syndrome. J Immunol. 2000;165(4): 2306-2312.

126. Lancefield RC. Persistence of type-specific antibodies in man following infection with group A streptococci. J Exp Med. 1959;110(2): 271-292.

127. Lancefield RC. Current knowledge of type-specific M antigens of group A streptococci. J Immunol. 1962;89:307-313.

128. Fox EN, Waldman RH, Wittner MK, Mauceri AA, Dorfman A. Protective study with a group A streptococcal M protein vaccine. Infectivity challenge of human volunteers. J Clin Invest. 1973;52(8):1885-1892.

129. Polly SM, Waldman RH, High P, Wittner MK, Dorfman A. Protective studies with a group A streptococcal M protein vaccine. II. Challange of volunteers after local immunization in the upper respiratory tract. J Infect Dis. 1975;131(3):217-224.

130. D’Alessandri R, Plotkin G, Kluge RM, et al. Protective studies with group A streptococcal $\mathrm{M}$ protein vaccine. III. Challenge of volunteers after systemic or intranasal immunization with type 3 or type 12 group A Streptococcus. J Infect Dis. 1978;138(6):712-718.

131. Stollerman GH. Rheumatic fever. Lancet. 1997;349(9056):935-942.

132. Lannergard J, Gustafsson MC, Waldemarsson J, Norrby-Teglund A, Stalhammar-Carlemalm M, Lindahl G. The hypervariable region of Streptococcus pyogenes $\mathrm{M}$ protein escapes antibody attack by antigenic variation and weak immunogenicity. Cell Host Microbe. 2011;10(2):147-157.

133. Bronze MS, Courtney HS, Dale JB. Epitopes of group A streptococcal $\mathrm{M}$ protein that evoke cross-protective local immune responses. J Immunol. 1992;148(3):888-893.

134. Jones KF, Fischetti VA. The importance of the location of antibody binding on the M6 protein for opsonization and phagocytosis of group A M6 streptococci. J Exp Med. 1988;167(3):1114-1123.

135. Bessen D, Fischetti VA. Influence of intranasal immunization with synthetic peptides corresponding to conserved epitopes of M protein on mucosal colonization by group A streptococci. Infect Immun . 1988;56(10):2666-2672.

136. Bessen D, Fischetti VA. Synthetic peptide vaccine against mucosal colonization by group A streptococci. I. Protection against a heterologous M serotype with shared C repeat region epitopes. J Immunol. 1990;145(4):1251-1256.

137. Guilherme L, Fae KC, Higa F, et al. Towards a vaccine against rheumatic fever. Clin Dev Immunol. 2006;13(2-4):125-132.

138. Guilherme L, Postol E, Freschi de Barros S, et al. A vaccine against S. pyogenes: design and experimental immune response. Methods. 2009;49(4):316-321.

139. Guerino MT, Postol E, Demarchi LM, et al. HLA class II transgenic mice develop a safe and long lasting immune response against StreptInCor, an anti-group A streptococcus vaccine candidate. Vaccine. 2011;29(46):8250-8256.

140. Guilherme L, Alba MP, Ferreira FM, et al. Anti-group A streptococcal vaccine epitope: structure, stability, and its ability to interact with HLA class II molecules. J Biol Chem. 2011;286(9):6989-6998. 
141. Pruksakorn S, Currie B, Brandt E, et al. Identification of T cell autoepitopes that cross-react with the $\mathrm{C}$-terminal segment of the $\mathrm{M}$ protein of group A streptococci. Int Immunol. 1994;6(8):1235-1244.

142. Brandt ER, Hayman WA, Currie B, et al. Opsonic human antibodies from an endemic population specific for a conserved epitope on the M protein of group A streptococci. Immunology. 1996;89(3):331-337.

143. Hayman WA, Brandt ER, Relf WA, Cooper J, Saul A, Good MF. Mapping the minimal murine $\mathrm{T}$ cell and $\mathrm{B}$ cell epitopes within a peptide vaccine candidate from the conserved region of the $\mathrm{M}$ protein of group A streptococcus. Int Immunol. 1997;9(11):1723-1733.

144. Quinn A, Kosanke S, Fischetti VA, Factor SM, Cunningham MW. Induction of autoimmune valvular heart disease by recombinant streptococcal M protein. Infect Immun. 2001;69(6):4072-4078.

145. Kemeny E, Grieve T, Marcus R, Sareli P, Zabriskie JB. Identification of mononuclear cells and $\mathrm{T}$ cell subsets in rheumatic valvulitis. Clin Immunol Immunopathol. 1989;52(2):225-237.

146. Guilherme L, Oshiro SE, Fae KC, et al. T-cell reactivity against streptococcal antigens in the periphery mirrors reactivity of heartinfiltrating $\mathrm{T}$ lymphocytes in rheumatic heart disease patients. Infect Immun. 2001;69(9):5345-5351.

147. Batzloff MR, Hayman WA, Davies MR, et al. Protection against group A streptococcus by immunization with J8-diphtheria toxoid: contribution of J8- and diphtheria toxoid-specific antibodies to protection. J Infect Dis. 2003;187(10):1598-1608.

148. Dunn LA, McMillan DJ, Batzloff M, et al. Parenteral and mucosal delivery of a novel multi-epitope $M$ protein-based group A streptococcal vaccine construct: investigation of immunogenicity in mice. Vaccine. 2002;20(21-22):2635-2640.

149. Olive C, Batzloff MR, Horvath A, et al. A lipid core peptide construct containing a conserved region determinant of the group A streptococcal $\mathrm{M}$ protein elicits heterologous opsonic antibodies. Infect Immun. 2002;70(5):2734-2738.

150. Sharma A, Arya DK, Sagar V, Bergmann R, Chhatwal GS, Johri AK. Identification of potential universal vaccine candidates against group A Streptococcus by using high throughput in silico and proteomics approach. J Proteome Res. 2013;12(1):336-346.
151. Rodriguez-Ortega MJ, Norais N, Bensi G, et al. Characterization and identification of vaccine candidate proteins through analysis of the group A Streptococcus surface proteome. Nat Biotechnol. 2006;24(2): 191-197.

152. Severin A, Nickbarg E, Wooters J, et al. Proteomic analysis and identification of Streptococcus pyogenes surface-associated proteins. J Bacteriol. 2007;189(5):1514-1522.

153. Lei B, Liu M, Chesney GL, Musser JM. Identification of new candidate vaccine antigens made by Streptococcus pyogenes: purification and characterization of 16 putative extracellular lipoproteins. J Infect Dis. 2004;189(1):79-89.

154. Rappuoli R. Reverse vaccinology. Curr Opin Microbiol. 2000;3(5): 445-450.

155. Bensi G, Mora M, Tuscano G, et al. Multi high-throughput approach for highly selective identification of vaccine candidates: the Group A Streptococcus case. Mol Cell Proteomics. 2012;11(6): M111.015693.

156. Dale JB. Multivalent group A streptococcal vaccine designed to optimize the immunogenicity of six tandem M protein fragments. Vaccine. 1999;17(2):193-200.

157. Kotloff KL, Corretti M, Palmer K, et al. Safety and immunogenicity of a recombinant multivalent group A streptococcal vaccine in healthy adults: Phase I trial. JAMA. 2004;292(6):709-715.

158. Hu MC, Walls MA, Stroop SD, Reddish MA, Beall B, Dale JB. Immunogenicity of a 26-valent group A streptococcal vaccine. Infect Immun. 2002;70(4):2171-2177.

159. Dale JB, Penfound TA, Tamboura B, et al. Potential coverage of a multivalent $\mathrm{M}$ protein-based group A streptococcal vaccine. Vaccine. 2013;31(12):1576-1581.

160. Brandt ER, Hayman WA, Currie B, Pruksakorn S, Good MF. Human antibodies to the conserved region of the $\mathrm{M}$ protein: opsonization of heterologous strains of group A streptococci. Vaccine. 1997;15(16): 1805-1812.
Vaccine: Development and Therapy

\section{Publish your work in this journal}

Vaccine: Development and Therapy is an international, peer-reviewed, open access journal that spans the spectrum of vaccine design and development through to clinical applications. The journal is characterized by the rapid reporting of application notes, reviews, original research and clinical studies in all therapeutic areas. Clinical outcomes, patient safety,

\section{Dovepress}

and programs for the development and effective, safe, and sustained use of vaccines will be a feature of the journal. The manuscript management system is completely online and includes a very quick and fair peer-review system. Visit http://www.dovepress.com/testimonials.php to read real quotes from published authors. 